\title{
Effect of supplementation of Kappaphycus alvarezii based seaweed product on rumen fermentation parameters under in vitro conditions
}

\author{
Avinesh Sharma ${ }^{1}$, Chander Datt ${ }^{1}$, Ritika Gupta ${ }^{1}$, Jitendra Kumar $^{2}$, Shambhvi $^{1}$, AK Tyagi $^{1}$ and Veena $_{\text {Mani }}{ }^{1}$
}

Received: 26 July 2019 / Accepted: 23 August 2019 / Published online: 28 October 2019

(C) Indian Dairy Association (India) 2019

\begin{abstract}
In vitro trials were conducted to study the effect of fortification of different levels of $K$. alvarezii based seaweed product (K. Alvarezii powder: Gracilaria salicornia powder: $K$. alvarezii sap powder in 1: 1: 1 ratio) to basal substrate on digestibility and rumen fermentation parameters. The results showed that supplementation of different levels $(0,0.5,1.0,1.5$, $2.0,2.5$ and $3.0 \%$ ) of $K$. alvarezii based seaweed product to the basal substrate consisting of sugargraze fodder (sorghum $\times$ sorgho $\times$ sudan grass hybrid) and concentrate mixture in 60: 40 ratio) did not affect in vitro true DM and OM digestibility, total gas production, methane production, ammonia- $\mathrm{N}$, microbial biomass production, individual volatile fatty acid production and metabolisable energy values to any significant extent.
\end{abstract}

Keywords: In vitro, Kappaphycus alvarezii, Fermentation, Methane, Gracilaria salicornia, Seaweed product, Volatile fatty acids

\section{Introduction}

India possesses 434 species of red seaweeds (Rhodophyta), 194 species of brown seaweeds (Phaenophyta) and 216 species of

\footnotetext{
${ }^{1}$ Animal Nutrition Division, ICAR-National Dairy Research Institute, Karnal-132001, Haryana, India

${ }^{2}$ Animal Biochemistry Division, ICAR-National Dairy Research Institute, Karnal-132001, Haryana, India

Chander Datt( $₫)$

Animal Nutrition Division, ICAR-National Dairy Research Institute, Karnal-132001, Haryana, India

E-mail: chandatt@gmail.com
}

green (Chlorophyta) seaweeds (Modayil, 2004). Kappaphycus alvarezii and Gracilaria salicornia are two important species of cultivated red seaweed targeted for carrageenan production which is mostly utilized as thickening agent and stabilizer in the food industry (Pang et al. 2010, Mondal et al. 2015). Seaweeds have been used as livestock feed for many years. The byproducts after extraction of carrageenan can be used as animal feed.

Evaluation of seaweeds or their byproducts using in vivo trials is time consuming, laborious and costly and in vitro evaluation is preferred in such investigations. Some literature exist on utilization of brown and green algae as supplements in pure form or in combination with two or three species (Bozic et al. 2009; Machado et al. 2014; El-Waziry et al. 2015), however, recently attention has been focused on utilization of red seaweeds for their nutritional benefits in ruminants which includes reduction in methane production (Rajauria, 2015). Thus, the present study was planned to investigate the effect of $K$. alvarezii based seaweed product on rumen fermentation parameters under in vitro conditions

\section{Materials and Methods}

\section{Substrate for In vitro fermentation}

Concentrate mixture and green fodder (sugargraze) were collected from Livestock Research Centre of ICAR-National Dairy Research Institute, Karnal, Haryana. The samples were dried in hot air oven at $65^{\circ} \mathrm{C}$ for 2 days until constant weight was attained. The dried samples were ground through $1 \mathrm{~mm}$ sieve using electrically operated Willey mill. The basal substrate was prepared using concentrate mixture and sugargraze fodder (sorghum $\times$ sorgho $\times$ sudan grass hybrid) fodder in 40:60 ratio on DM basis. Basal substrate was fortified with varying levels of commercially available Kappaphycus alvarezii based seaweed product (SWP; M/s AQUAAGRI Processing Pvt. Ltd., Manamadurai, Tamilnadu) consistedof $K$. alvarezii powder, Gracilaria salicornia powder and $K$. alvarezii sap powder in 1: 1: 1 ratio. Substrate components and SWP were analysed for proximate principles (AOAC, 2005) and cell wall constituents (Van Soest et al. 1991). 


\section{In vitro rumen fermentation studies}

In vtiro rumen fermentation of total mixed substrate with varying levels of SWP such as; 0, 0.5, 1.0, 1.5, 2.0, 2.5 and 3.0\%. was carried out using 6 replicates each. Rumen liquor was collected from 3 male adult crossbred cattle maintained to meet the nutrient requirement (ICAR, 2013) prior to feeding and watering, strained using musclin cloth into a pre-warmed thermos flask and brought immediately to the laboratory. The incubations were carried out in $100 \mathrm{~mL}$ calibrated glass syringes (Menke and Steingass, 1988). The proportion of medium mixture solution to rumen liquor was 2: 1. Just after mixing the medium and rumen liquor, $30 \mathrm{~mL}$ of incubation medium was injected to the syringes using auto dispenser. The syringes were shaken gently and residual air or air bubbles, if any, was removed and outlet was closed At the end of the incubation, $5 \mu$ Lof gas was withdrawn using Hamilton gas tight syringe and analyzed for its methane level with the help of Gas Chromatograph (Nucon 5700, India) fitted with stainless steel column packed with Porapak-N and Flame Ionization Detector (FID). The standard gas used for methane estimation (Spantech House, Surrey, England) composed of 50\% methane and 50\% $\mathrm{CO}_{2}$. Subsequently, substrate and inoculum was recovered. Substrate was analysed for true DM and OM digestibility (TDMD and TOMD) according to Van Soest et al. (1991).

For analysis of individual fatty acids (IVFA), the rumen fermentation was arrested by chilling at $4^{\circ} \mathrm{C}$ and the syringe contents were then centrifuged at $3000 \mathrm{rpm}$ for $10 \mathrm{~min}$. A portion of $5 \mathrm{~mL}$ of supernatant was added to $1 \mathrm{~mL}$ of $25 \%$ metaphosphoric acid and kept overnight at $4^{\circ} \mathrm{C}$ (Patra et al. 2006). The mixture was centrifuged at $3000 \mathrm{rpm}$ for $15 \mathrm{~min}$. and $2 \mathrm{~mL}$ of supernatant was taken and stored at $-20^{\circ} \mathrm{C}$ for VFA analysis. The individual VFA in the samples were determined using Gas Chromatograph (Nucon 5700, Nucon Engineers, New Delhi) equipped with flame ionization detector and stainless steel column packed with chromosorb 101 mesh 80-100 (length $1.5 \mathrm{~m}$; o.d $3.175 \mathrm{~mm}$; i.d. $2 \mathrm{~mm}$ ). Analytical conditions for fractionation of VFA were as follows: Injection port temperature $210^{\circ} \mathrm{C}$, column temperature $180^{\circ} \mathrm{C}$ and detector temperature $230^{\circ} \mathrm{C}$. The flow rate of the carrier gas $\mathrm{N}_{2}$ was $40 \mathrm{~mL} /$ min). Individual volatile fatty acids (Acetate, propionate and butyrate) in the samples were determined on the basis of retention time and their concentration was calculated by comparing the retention time as well as the peak area of the standard after blank correction.

For estimation of $\mathrm{NH}_{3}-\mathrm{N}, 5 \mathrm{~mL}$ of acidified supernatant was mixed with $10 \mathrm{~mL}$ of $\mathrm{NaOH}(1 \mathrm{~N})$ and immediately steam distilled using KEL PLUS $®$ - $\mathrm{N}$ analyzer (Pelican, India). The $\mathrm{NH}_{3}$ evolved was collected in boric acid solution $(20 \% \mathrm{w} / \mathrm{v})$ having mixed indicator and titrated against $\mathrm{N} / 100 \mathrm{H}_{2} \mathrm{SO}_{4}$.

Metabolizable energy (ME) was calculated using the prediction equation of Menke and Steingass (1988). Microbial biomass production (MBP) was calculated using data of TDOM and net gas volume (Blummel et al. 1997; Blummel and Lebzien, 2001).

\section{Statistical analysis}

The data were analyzed by two-way ANOVA and difference between the means was compared by Turkey's-B multiple range test as per Snedecor and Cochran (1994) using software package SPSS version 20.0 (2012).

\section{Results and Discussion}

\section{Chemical composition of feeds/sea weed product}

The concentrate mixture contained $20.50 \% \mathrm{CP}$ and $4.33 \% \mathrm{EE}$, $30.26 \%$ NDF and $14.20 \%$ ADF on DM basis. Sugargraze fodder had $8.78,1.73,53.43$ and $30.42 \%$ of CP, EE, NDF and ADF, respectively. The total ash content in sea weed product was $72.55 \%$ and it possessed $5.58 \% \mathrm{CP}$ and $1.98 \% \mathrm{EE}$ (Table 1).Thus, SWP contained very high level of total ash while CP level was lower in comparison to concentrate mixture and sugargraze fodder. $K$. alvarezii collected from Malaysia contained 66.66, 23.25, 5.35, $4.50,0.23 \% \mathrm{CHO}$, total ash, protein, fibre and lipid, respectively (Ahmad et al. 2012) indicating that type of seaweed or formulated product affect the chemical composition.

\section{In vitro evaluation of SWP}

TDMD and TOMD were $81.05 \pm 0.45$ and $82.31 \pm 2.78 \%$, respectively. The total gas production was $4.50 \pm 0.28 \mathrm{~mL} / 200 \mathrm{mg}$ substrate or $27.50 \pm 1.44 \mathrm{~mL} / \mathrm{g}$ substrate. Methane production was $1.37 \pm 0.02 \mathrm{~mL} / 200 \mathrm{mg} \mathrm{DM}$ and this represented $25.05 \pm 0.38 \%$ of total gas production. The values of TDMD and TOMD of SWP as found in the present study were higher as compared to other studies. The values of OMD reported by El-Waziry et al. (2015) were lower than that reported for brown algae mixture (L. digitata and L. hyperborean) in vitro (78.3\%) by Hasen et al. (2003) and for U. lactuca (62.1\%) by Ventura and Castanon (1998) and also less $(60 \%)$ than that reported for U. lactuca (Arieli et al. 1993). The in vivo energy digestibility of Ulva lactuca in young rams has been reported as $60 \%$ (Arieli et al. 1993). The in vitro OM digestibility of brown and red seaweeds when measured with rumen fluid obtained from seaweed-fed sheep was found to be higher for brown algae Laminaria digitata (94\%), Saccharina latissima (97\%) and Alaria esculenta (81\%) and red algae Palmaria palmata (81\%). However, it was lower for other brown seaweeds such as Ascophyllum nodosum (33\%), Fucus serratus (15\%) and Fucus vesiculosus (26\%) (Greenwood et al. 1983). In comparison to brown algae, Macrocystis pyrifera and Sargassum sp., the in situ DM degradability of Macrocystis pyrifera was found to be lower (50\%) but higher than that of Sargassum (29\%) due to a better composition of the former. Degradability values for the green algae, Ulva lactuca were also relatively lower (54 and $41 \%$ for OM and protein, respectively) as reported by Arieli et al. (1993). The ME value of SWP in the present study was 2.86 $\mathrm{MJ} / \mathrm{kg}$ DM which was 3.3 times lesser than estimate of Ventura and Castanon (1998) in seaweed.. The high mineral content of 
seaweeds limits their gross, digestible, metabolisable and net energy values (Arieli et al. 1993).

\section{Supplementary effects of SWP on rumen fermentation variables}

The total gas production ranged from 34.50 to $38.25 \mathrm{~mL} / 200 \mathrm{mg}$ substrate and methane production from 7.51 to $9.16 \mathrm{~mL} / 200 \mathrm{mg}$ substrate in treatments supplemented with 0-3\% SWP in the substrate (Table 2). Methane production varied from 21.01 to $25.81 \%$ of total gas production. Statistical analysis showed that supplementation of SWP@0-3\% of the substrate did not affect total gas and methane production to any significant level.

The TDMD values ranged from 68.25 to $72.35 \%$ while TOMD values varied from 71.60 to $75.10 \%$ across the treatments (Table
3). MEvalues ranged from 6.88 to $8.39 \mathrm{MJ} / \mathrm{kg} \mathrm{DM}$ and the MBP values ranged from 40.54 to $46.76 \mathrm{mg} / \mathrm{tube}$. The $\mathrm{NH}_{3}-\mathrm{N}$ concentration ranged from 10.03 to $11.42 \mathrm{mg} / \mathrm{dL}$. TDMD, TOMD, $\mathrm{ME}, \mathrm{MBP}$ and $\mathrm{NH}_{3}-\mathrm{N}$ were comparable between control and treatments. The proportion of acetate, propionate and butyrate ranged from 66.44 to $68.33 \%$, from 24.61 to $27.85 \%$ and from 5.01 to $8.50 \%$, respectively (Table 4 ). Acetate: propionate ratio was 2.40 to 2.48 . Our results are in conformity with those of (El-Waziry et al.2015) who reported no significant differences in the potential degradability, gas production rate, ME, net energy, OMD and MBP synthesis in diets supplemented with 3 and $5 \%$ of Ulva lactuca. On the other hand, there was reduction in enteric $\mathrm{CH}_{4}$ production due to macroalgae supplementation (Wang et al. 2008; Bozic et al. 2009). Addition of sea seaweeds showed inhibitory effect on rumen fermentation resulting in decreased total gas

Table 1 Chemical composition of feed stuffs used for in vitro studies

\begin{tabular}{lllc}
\hline Parameter & Concentrate mixture & Sugargraze & Seaweed product \\
\hline Dry matter & 89.9 & 22.25 & 94.6 \\
Organic matter & 92.72 & 90.28 & 27.45 \\
Crude protein & 20.5 & 8.78 & 5.58 \\
Total ash & 7.28 & 9.72 & 72.55 \\
Ether extract & 4.33 & 1.73 & 1.98 \\
Neutral detergent fibre & 30.26 & 53.43 & 15.03 \\
Acid detergent fibre & 14.2 & 30.42 & 9.92 \\
\hline
\end{tabular}

Table 2 In vitro gas and methane production from TMR supplemented with graded levels of sea weed product

\begin{tabular}{llll}
\hline $\begin{array}{l}\text { Level of SWP } \\
\text { supplementation (\%) }\end{array}$ & $\begin{array}{l}\text { Total gas } \\
\text { production }(\mathrm{mL} / 200 \mathrm{mg} \\
\text { substrate) }\end{array}$ & $\begin{array}{l}\mathrm{CH}_{4} \text { production } \\
(\mathrm{mL} / 200 \mathrm{mg} \mathrm{DM})\end{array}$ & $\mathrm{CH}_{4}$ production (\%) \\
\hline 0 & $34.50 \pm 0.64$ & $8.10 \pm 0.09$ & $23.49 \pm 0.28$ \\
0.5 & $37.00 \pm 1.08$ & $8.62 \pm 0.33$ & $23.29 \pm 0.87$ \\
1 & $35.75 \pm 2.59$ & $7.51 \pm 0.20$ & $21.01 \pm 0.56$ \\
1.5 & $38.25 \pm 1.25$ & $9.02 \pm 0.96$ & $23.58 \pm 2.51$ \\
2 & $35.50 \pm 0.65$ & $8.31 \pm 0.10$ & $23.43 \pm 0.30$ \\
2.5 & $35.50 \pm 0.96$ & $9.16 \pm 0.13$ & $25.81 \pm 0.37$ \\
3 & $35.00 \pm 1.96$ & $8.41 \pm 0.10$ & $24.04 \pm 0.31$ \\
\hline
\end{tabular}

Table 3 Effect of supplementation of graded levels of sea weed product on digestibility, microbial biomass and energy value under in vitro conditions

\begin{tabular}{lccccc}
\hline $\begin{array}{l}\text { Level of SWP } \\
\text { supplementation (\%) }\end{array}$ & TDMD (\%) & TOMD $(\%)$ & ME $(\mathrm{MJ} / \mathrm{kg})$ & $\mathrm{MBP}(\mathrm{mg})$ & $\mathrm{NH}_{3-} \mathrm{N}(\mathrm{mg} / 100 \mathrm{~mL})$ \\
\hline 0 & $71.61 \pm 1.15$ & $72.67 \pm 0.57$ & $6.88 \pm 0.13$ & $46.76 \pm 0.29$ & $10.03 \pm 0.37$ \\
0.5 & $72.08 \pm 0.84$ & $74.67 \pm 0.22$ & $8.22 \pm 0.27$ & $41.00 \pm 6.18$ & $10.11 \pm 0.51$ \\
1 & $68.90 \pm 1.14$ & $71.60 \pm 2.50$ & $8.05 \pm 0.16$ & $42.67 \pm 0.99$ & $10.40 \pm 0.32$ \\
1.5 & $72.35 \pm 0.67$ & $75.10 \pm 0.75$ & $8.39 \pm 0.10$ & $41.75 \pm 3.07$ & $11.21 \pm 0.75$ \\
2 & $68.25 \pm 1.09$ & $71.60 \pm 1.80$ & $8.02 \pm 0.19$ & $40.54 \pm 6.97$ & $11.10 \pm 0.35$ \\
2.5 & $70.10 \pm 2.12$ & $73.45 \pm 2.1$ & $8.02 \pm 0.28$ & $40.85 \pm 4.15$ & $11.33 \pm 0.32$ \\
3 & $72.32 \pm 0.16$ & $74.97 \pm 0.12$ & $7.95 \pm 0.17$ & $46.67 \pm 2.74$ & $11.42 \pm 0.55$ \\
\hline
\end{tabular}

TDMD: true dry matter digestibility, TOMD: true organic matter digestibility, ME: metabolisable energy, MBP: microbial biomass production 
Table4 Individual VFA's as affected by addition of seaweed product at graded levels

\begin{tabular}{lllll}
\hline $\begin{array}{l}\text { Level of SWP } \\
\text { supplementation (\%) }\end{array}$ & Acetate & Propionate & Butyrate & Acetate: propionate ratio \\
\hline Control & $67.37 \pm 0.78$ & $26.62 \pm 1.69$ & $6.03 \pm 0.2$ & $2.56 \pm 0.18$ \\
0.5 & $66.88 \pm 1.24$ & $24.77 \pm 0.78$ & $8.50 \pm 1.57$ & $2.70 \pm 0.10$ \\
1 & $67.34 \pm 1.00$ & $27.63 \pm 0.22$ & $5.01 \pm 0.89$ & $2.43 \pm 0.05$ \\
1.5 & $68.33 \pm 2.08$ & $24.61 \pm 0.88$ & $7.04 \pm 2.47$ & $2.78 \pm 0.11$ \\
2 & $66.66 \pm 1.35$ & $27.95 \pm 1.33$ & $5.38 \pm 0.63$ & $2.40 \pm 0.17$ \\
2.5 & $66.44 \pm 1.09$ & $25.30 \pm 0.70$ & $8.24 \pm 0.46$ & $2.63 \pm 0.12$ \\
3 & $66.46 \pm 0.86$ & $26.88 \pm 0.43$ & $6.64 \pm 1.01$ & $2.47 \pm 0.04$ \\
\hline
\end{tabular}

production, methane production and volatile fatty acids production under in vitro conditions (Machado et al. 2014). There were no significant changes in digestibility of nutrients in Sahiwal cows when mineral mixture $(3 \%)$ in the concentrate was replaced by $20 \%$ Sargassum wightii (Singh et al. 2015).

\section{Conclusions}

The supplementation of $K$. Alvearzii based seaweed product at $0,0.5,1.0,1.5,2.0,2.5$ and $3.0 \%$ level of substrate containing sugargraze and concentrate mixture in 60: 40 ratio did not affect in vitro $\mathrm{DM}$ and $\mathrm{OM}$ digestibility, rumen fermentation parameters (IVGP, IVFA, $\mathrm{NH}_{3}-\mathrm{N}$ and microbial biomass production) and $\mathrm{ME}$ values

\section{Acknowledgements}

We are grateful to Director, ICAR-National Dairy Research Institute, Karnal, Haryana for providing necessary facilities to carry out this work. The financial assistance received under CSIRNew Millennium Indian Technology Leadership Initiative programme (Kappaphycus alvarezii and red sea weed based formulations for improving productivity and health of dairy animal and poultry) is greatly acknowledged.

\section{References}

Ahmad F, Sulaiman MR, Saimon W, Yee CF, Matanjun P (2012) Proximate compositions and total phenolic contents of selected edible seaweed from Semporna, Sabah, Malaysia. Borneo Sci 31: 74

AOAC (2005) Official Methods of Analysis. $18^{\text {th }}$ edn. Association of Official Analytical Chemists. Maryland, U.S.A.

Arieli A, Sklan D, Kissil G (1993) A note on the nutritive value of Ulva lactuca for ruminants. Anim Prod 57: 329-331

Blummel M, Lebzien P (2001) Predicting ruminal microbial efficiencies of dairy rations by in vitro techniques. Livest Prod Sci 68: 107-117

Blummel M, Makkar HPS, Becker K (1997) In vitro gas production: a technique revisited. J Anim. Physiol. Anim Nutr 77: 24-34

Bozic AK, Anderson RC, Carstens GE, Rick SC, Callaway TR, Yokoyama MT, Nisbet DJ (2009) Effects of the methane-inhibitors nitrate, nitroethane, lauric acid, Lauricidin and the Hawaiian marine algae Chaetoceros on ruminal fermentation in vitro. Bioresource Technol 100: 4017-4025

El-Waziry A, Al-Haidary A, Okab A, Samara E, Abdoun K (2015) Effect of dietary seaweed (Ulva lactuca) supplementation on growth performance of sheep and on in vitro gas production kinetics. Turk J Vet Anim Sci 39: 81-86
Greenwood Y, Orpin CG, Paterson I.W (1983) Digestibility of seaweeds in Orkney sheep. J Physiol 343: 120

Hansen HR, Hector BL, Feldmann J (2003) A qualitative and quantitative evaluation of the seaweed diet of North Ronaldsay sheep. Anim Feed Sci Technol 105: 21-28

ICAR (2013) Nutrient Requirements of Cattle and Buffaloes. $3^{\text {rd }}$ edn. Indian Council of Agricultural Research, New Delhi, India.

Modayil MJ (2004) How to increase marine fish production. Fishing Chimes 28: $14-16$

Mondal D, Ghosh A, Prasad P, Singh S, Bhatt N, Zodape ST, Chaudhary JP, Chaudhari J, Chatterjee PB, Seth A, Ghosh PK (2015) Elimination of gibberellin from Kappaphycus alvarezii seaweed sap foliar spray enhances corn stover production without compromising the grain yield advantage. Plant Growth Regul 75: 657-666

Pang SM, Yeong HY, Lim PH, Nor AR, Gan KT (2010) Commercial varieties of Kappaphycus and Eucheuma in Malaysia. Malasian J Sci 29: 214-224

Patra AK, Kamra DN and Agarwal N (2006) Effect of plant extracts on in vitro methanogenesis, enzyme activities and fermentation of feed in rumen liquor of buffalo. Anim Feed Sci Technol 128: 276-291

Machado L, Magnusson M, Paul NA, de Nys R, Tomkins N (2014) Effects of marine and freshwater macroalgae on in vitro total gas and methane production. PLoS ONE 9: e85289. doi:10.1371/ journal.pone. 0085289

Menke KH, Steingass H (1988) Estimation of the energetic feed value obtained from chemical analysis and in vitro gas production using rumen fluid. Anim Res Dev 28: 7-55

Rajauria G (2015) Seaweeds: A sustainable feed resource for livestock and aquaculture. In: Seeweed Sustainability: Food and Non-food Application (Brijesh K. Tiwari and Declan J. Troy; Eds.), Academic Press, Elsevier Inc., USA. pp 389-420

Singh BK, Chopra RC, Rai SN, Verma MP and Mohanta RK (2015) Nutritional evaluation of seaweed on nutrient digestibility, nitrogen balance, milk production and composition in Sahiwal cows. Proc. Natl. Acad. Sci. India, Sect. B: Biol Sci 1-7

Snedecor GW, Cochran WG (1994) Statistical Methods. $8^{\text {th }}$ edn. The Iowa State University Press, Ames, Iowa, USA

Van Soest PJ, Robertson JB, Lewis BA (1991) Methods for dietary fibre, neutral detergent fiber and non-starch polysaccharides in relation to animal nutrition. J Dairy Sci 74: 3583-3597

Ventura MR, Castaòoñ JIR (1998) The nutritive value of seaweed (Ulva lactuca) for goats. Small Rumin Res 29: 325-327

Wang Y, Xu Z, Bach SJ, McAllister TA (2008) Effects of phlorotannins from Ascophyllum nodosum (brown seaweed) on in vitro ruminal digestion of mixed forage or barley grain. Anim. Feed Sci Technol 145: $375-395$ 